\title{
SUNKI DIFUZINIO ATOPINIO DERMATITO FORMA SU DAUGINĖS ALERGIJOS MAISTUI SINDROMU IR PIRMINIU IMUNODEFICITU. KLINIKINIS ATVEJIS
}

\author{
Evelina Bučionyte் $\dot{1}^{1}$ Agnè Čibirkaitė ${ }^{1}$, Vilija Bubnaitiene் $\dot{e}^{2}$ \\ ${ }^{1}$ Lietuvos sveikatos moksly universiteto Medicinos fakultetas, \\ ${ }^{2}$ Lietuvos sveikatos mokslu universiteto ligonine Kauno klinikos, Vaiku ligu klinika
}

Raktažodžiai: atopinis dermatitas (AD), dauginès alergijos maistui sindromas, pirminis imunodeficitas, vaikai.

\begin{abstract}
Santrauka
Atopinis dermatitas (AD) yra lètinè, banguojančios eigos odos liga, dažniausiai sukelianti stiprų odos niežèjimą ir vientisumo pažeidimą. AD serga 20 proc. kūdikių ir vaikų iki 2 metų, iš kurių maždaug trečdalio simptomai siejami su alergija maistui. AD kartais pasireiškia su pirminiu imunodeficitu, o AD sergančių vaikų odą neretai kolonizuoja Staphylococcus aureus (S. aureus). AD gali būti sunki liga, kurią gali sukelti su IgE susijusios arba nesusijusios bei mišrios imuninès reakcijos. Nuo AD sukèlusio mechanizmo priklauso diagnostinių tyrimų pasirinkimas bei simptomų kontrolei naudojamų vaistų paskyrimas. Esant sunkiai AD formai su dauginès alergijos maistui sindromu ir pirminiu imunodeficitu, gyvenimo kokybę gerina tinkamas kompleksinis gydymas. Darbo tikslas - remiantis mokslinès literatūros šaltinių analize, išnagrinèti ir pristatyti sunkios formos atopinio dermatito atvejị, kuris pasireiške kūdikiui kartu su dauginès alergijos maistui sindromu bei pirminiu imunodeficitu.
\end{abstract}

\section{Ivadas}

Atopinis dermatitas (AD), dar žinomas kaip atopinè egzema, yra aktuali kūdikių ir vaikų sveikatos problema. AD suserga 20 proc. kūdikių ir vaikų iki 2 metų [1]. Sunkus $A D$ vaikystejje labai pablogina gyvenimo kokybę dèl dažnai prisidedančių antrinių infekcijų ir ligos sukeliamų psichosocialinių problemų [2]. Apie 35 proc. vidutinio sunkumo ir sunkaus atopinio dermatito atvejų išprovokuoja maisto alergenai. Nesant atsako ì pirmo pasirinkimo medikamentini gydymą, būtina apsvarstyti dietos reikšmę simptomų kontrolei [3]. Nors vietinių preparatų vartojimas yra svarbiausias pasirinkimas gydant $\mathrm{AD}$, tačiau norint kontroliuoti ligos eigą, svarbu išsiaiškinti maisto alergenų itaką AD simptomų paūmèjimui ir užtikrinti, kad vaiką prižiūrètų visi būtini specialistai [4].

Šiame straipsnyje aprašomas retas, sunkios formos difuzinio atopinio dermatito atvejis, pasireiškęs kartu su dauginès alergijos maistui sindromu ir pirminiu imunodeficitu.

Darbo tikslas - supažindinti ịvairių specialybių gydytojus su retai pasitaikančiu sunkios formos difuzinio atopinio dermatito atveju, pasireiškusio kartu su dauginès alergijos maistui sindromu ir pirminiu imunodeficitu.

\section{Klinikinis atvejis}

3 mẻnesių kūdikis, beriamas nuo 2 mẻn. amžiaus, konsultuotas vaikų alergologo Lietuvos sveikatos mokslų universiteto ligoninès Kauno klinikų (LSMUL KK) Vaikų ligų konsultacinejje poliklinikoje. Atlikus odos dūrio mèginius (ODM) ir ištyrus specifinių IgE maistui bei ịkvepiamiems alergenams kiekị kraujyje, nustatytas ịsijautrinimas karvès pienui, kiaušinio baltymui, avižoms, sojai, šuniui. Šeimoje nustatytas ne vienas pirmos eilès giminaitis, sergantis alerginèmis ligomis: mama beriama nuo nikelio; tèvas serga šienlige, nuolatiniu alerginiu rinitu, alergiškas katei; močiutè serga alergine astma, alergiška katei, šuniui. Kūdikis, pablogejus odos būklei (1 pav.), stacionarizuotas gydymui. SCORAD indeksas prieš gydymą - 96,4 balai. Diagnozuotas sunkios formos atopinis dermatitas. Kūdikis maitinamas tik motinos pienu, tad mamai skirta hipoalerginè dieta, kūdikiui - gydymas emolientais, cetirizinu per os, prednizolonu per $o s$, vietiniais steroidais.

Grị̌uus namo, mama, maitinanti kūdikị natūraliai, toliau laikèsi hipoalerginès dietos, kūdikio odos priežiūrai pastoviai naudojo emolientus, kuriuos vèliau, jos žodžiais ,nesant efekto", pakeitė natūraliais kiaulių taukais, o pablogejjus odos būklei, epizodiškai naudojo vietinius steroidus, cetiriziną per os. 
Kūdikio odos būklè palaipsniui blogèjo, dažnėjo tuštinimasis skystomis išmatomis, krito kūno svoris, todèl 6 mèn. amžiaus pacientas pakartotinai stacionarizuotas atopinio dermatito paūmèjimo gydymui. Apžiūrint, galvos (įskaitant skalpo), liemens, galūnių oda difuziškai sausa, lichenifikuota, išberta susiliejančio papulinio-lichenoidinio berimo plotais. Bèrimo vietose oda paraudusi, induruota, ypač kaktos, skruostų, smakro srityse. Yra šašelių, erozijų (2-4 pav.).

Bendrame kraujo tyrime viso stacionarinio gydymo metu stebèta leukocitozè $\left(32-21,2 \times 10^{9} / 1\right)$, vyraujant limfocitams $\left(15,1-11,0 \times 10^{9} / 1\right)$ ir eozinofilams $\left(18,96-4,77 \times 10^{9} / 1\right)$. Ivvertinus klinikinius simptomus bei bendrą kraujo tyrimą, įtarus Omenn sindromą, atliktas imunologinis ištyrimas. Imunogramoje rastas padidejęs T limfocitu (CD3+) kiekis $-8,977 \times 10^{9} / 1$ (amžiaus norma - 0,7-4,2x10 $/ 1$ ), vyraujant $\mathrm{T}$ limfocitams pagalbininkams - induktoriams (CD4+) $6,698 \times 10^{9} / 1$ (amžiaus norma $-0,03-0,2 \times 10^{9} / 1$ ), bei padidèjęs B limfocitų (CD19+) kiekis - 2,633×10\%/1 (norma - 0,2-1,6 $\left.\mathrm{x} 10^{9} / 1\right)$. Tiriant imunoglobulinus, rastas ženkliai padidèjęs bendro IgE kiekis - 679,4-900,0 kU/1 (amžiaus norma iki $20 \mathrm{kU} / \mathrm{l}$ ) ir sumažèjęs IgG kiekis - 1,6 g/l (amžiaus norma 1,8-8 g/l), esant visų jo poklasių kiekio sumažèjimui (IgG1< $0,89 \mathrm{~g} / 1$, amžiaus norma 2-7,7 g/l; IgG2 - 0,26 g/l, amžiaus norma $0,34-2,3 \mathrm{~g} / \mathrm{l} ; \mathrm{IgG} 3<0,1 \mathrm{~g} / 1$, amžiaus norma $0,15-0,97$ $\mathrm{g} / 1 ; \operatorname{IgG} 4<0,08 \mathrm{~g} / 1$, amžiaus norma $0,012-0,43 \mathrm{~g} / 1)$, bei saikiai sumažejjęs IgA kiekis $(0,1 \mathrm{~g} / 1$; amžiaus norma $0,11-1,31$ g/l). Neutrofilu nitromėlio tetrazolio mèginys (angl. Nitroblue tetrasolium test, sutr. NBT ) buvo normos ribose, sieke 25 proc. (norma 15-25\%). Kartotinai tiriant IgG, jo kiekis vèl rastas sumažejęs - 1,68 g/l. Kūdikis iki 4 mèn. skiepytas pagal privalomų profilaktinių skiepijimų kalendorių, tirtas

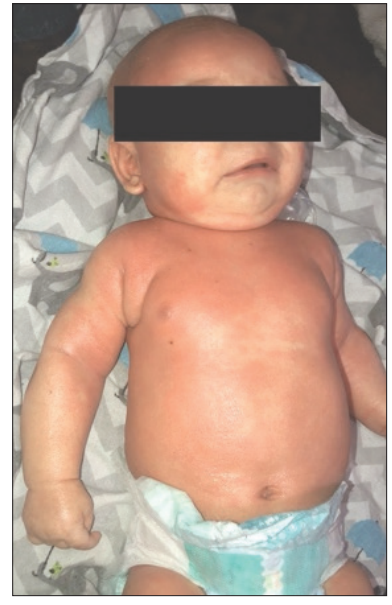

1 pav. Viso kūno bèrimas, paraudusi, sausa, šerpetojanti oda, seborèjinis bėrimas skalpo odoje

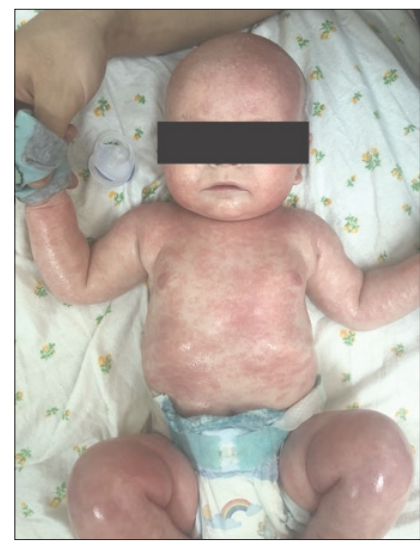
plotais; yra šašelių, erozijų atsakas į nuo T ląstelių priklausomą antigeną - hepatito B virusą; antikūnų prieš hepatito $\mathrm{B}$ paviršinį antigeną (anti-HBs) nerasta. Itarta gretutinè liga - iprastas kintamasis imunodeficitas (İID). Odos ir žaizdų pasèliuose rastas gausiai augantis Staphylococcus aureus (S. aureus), atsparus penicilinui, jautrus oksacilinui, sulfonamidui ir trimetoprimui. Skirtas gydymas cetirizinu per os, klemastinu per os, prednizolonu per os, pimekrolimo kremu veido, kaklo, raukšlių sritims, cefazolinu i veną (i/v). Gydymas prednizolonu per os, palaipsniui mažinant dozę, ir cefazolinu ị/v tęstas 14 dienų. Pradejus paskirtą gydymą, odos būklè èmé gerèti. SCORAD indeksas gydymo eigoje sumažèjo nuo 102,4 iki 93,4 balų. Aptarus paciento būklę gydytojų vaikų alergologų konsiliumo metu, nuspręsta skirti pakaitinę terapiją intraveniniu žmogaus normaliuoju imunoglobulinu (IgG) Octagam, kas 4 sav. kartotinai tiriant IgG kiekį kraujyje.

Pakaitinę terapiją intraveniniu žmogaus normaliuoju imunoglobulinu Octagam kūdikis toleravo gerai, šalutinių reakcijų nebuvo. Pradètas papildomas maitinimas, vengiant nustatytų maisto alergenų. Po kelių mėnesių tęstinio gydymo, kūdikio odos būklè ženkliai pagerèjo: oda sausa, vietomis lichenifikuota, tačiau bėrimai, paraudimas, šašeliai išliko tik skruostų, smakro, dešinès plaštakos ir dešinès blauzdos srityse. SCORAD indeksas siekè 35 balus. Po penktos Octagam dozès, IgG kiekiui paciento kraujyje išliekant normos ribose ( $\operatorname{IgG}$ - 5,2-4,3 g/l; amžiaus norma 3-10 g/l), negalint galutinai atmesti praeinančios kūdikių hipoglobulinemijos, pakaitinè imunoterapija intraveniniu žmogaus normaliuoju imunoglobulinu nutraukta, toliau stebint IgG kiekio kraujyje pokyčius.

Po kurio laiko pacientas vèl atvyko vaikų alergologo konsultacijai dèl AD paūmèjimo. Stebèta difuziškai sausa, vietomis lichenifikuota viso kūno oda, nukasymo žymės. Skruostuose, kairiojo dilbio ir dešinès kojos lenkiamuosiuose
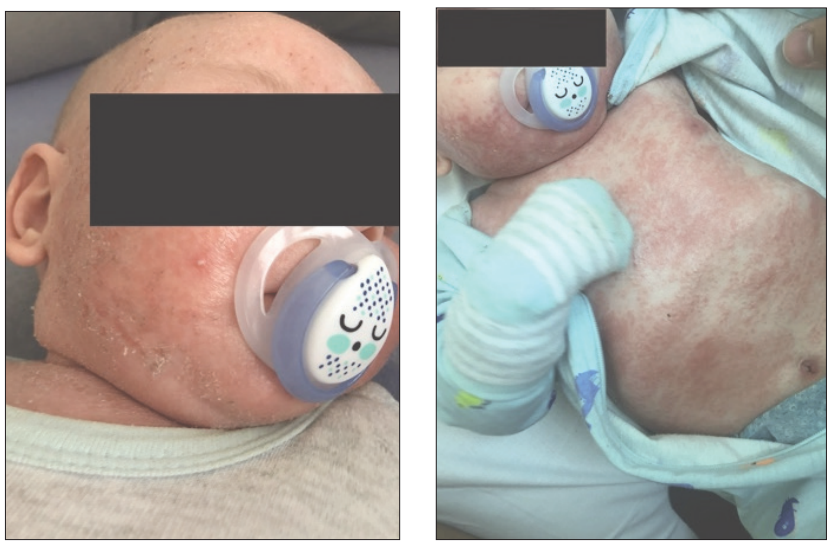

2-4 pav. Oda difuziškai sausa, lichenifikuota, išberta susiliejančio papulinio-lichenoidinio bėrimo 
paviršiuose, liemens srityje - papulinio-lichenoidinio bėrimo ploteliai, padengti šašeliais. SCORAD indeksas sieké 64,3 balus. Skyrus priešalergini gydymą, odos būklè kiek pagerèjo, SCORAD indeksas sumažèjo iki 51,8 balo.

Prieš paūmëjant atopiniam dermatitui, pacientui kelis kartus buvo pasireiškęs dilgèlinis bẻrimas su angioedema akių vokų ir veido srityse, mamai prisilietus prie vaiko rankomis po maisto (patiekalų iš žuvies, kiaušinių) gamybos, todèl kelis kartus vyko i LSMUL KK vaikų skubiosios pagalbos skyrių. 12 mėnesių pacientui pakartotinai atliktas alergologinis ištyrimas. ODM su maisto alergenais pagalba nustatytas isijautrinimas kiaušinio baltymui (4+), kiaušinio tryniui (4+), rugiams (2+), kviečiams (1+), avižoms $(2+)$, pienui (1+), vištienai (4+), menkei (4+). Specifinių IgE kraujyje pagalba nustatytas įsijautrinimas beržui $(2,05 \mathrm{kU} / 1,2 \mathrm{kl}$.), šuniui $(6,15$ kU/1, 3 kl.), katei (10,78 kU/1, 3 kl.), arkliui (2,05 kU/1, 2 kl.), kiaušinio baltymui (45,5 kU/1, 4 kl.), kiaušinio tryniui (3,4 kU/1, 2 kl.), karvès pienui (77,56 kU/1, 5 kl.), jaučio serumo albuminui (83,69 kU/1, $5 \mathrm{kl}$.), kvietiniams miltams (12,77 kU/1, 3 kl.), bulvei (46,38 kU/1, 4 kl.), menkei (12,1 $\mathrm{kU} / 1,3 \mathrm{kl}$.), lazdyno (0,35 kU/1, $1 \mathrm{kl}$.) bei žemės riešutams (2,95 kU/l, 2 kl.), ryžiams (57,96 kU/l, $5 \mathrm{kl}$.), sojos pupelèms (72,66 kU/1, $5 \mathrm{kl}$.). Odos lopo méginiai (OLM) su maistu po 48 ir 72 val. buvo teigiami kviečiams, sojai, migdolams, kakavai.

1 metų ir 3 mėnesių pacientui pasireiškus anafilaksinei reakcijai, kurios priežastis buvo nevisiškai aiški, atliktas ir ALEX2 makrogardelès molekulinis 117 alergenų šaltinių ir 178 jų komponentų tyrimas, kurio metu nustatytas ịsijautrinimas 66 alergenų šaltiniams ir jų komponentams: medžių žiedadulkèms (2), ankštiniams (4), grūdiniams maisto produktams (3), prieskoniams (2), daržovėms (2), riešutams ir sẻkloms (4), kiaušiniui (3), žuvims ir jūros gèrybėms (3), mėsai (4), naminiams augintiniams (3), gyvuliams (3) (0 - neigiamas arba abejotinas, 1 - mažas, 2 - vidutinis, 3 didelis, 4 - labai aukštas IgE kiekis). Atsižvelgiant ị tyrimo rezultatus, sunkias anafilaksines reakcijas pacientui galètu sukelti žemės riešutai, kviečiai, garstyčios, anakardžiai, lazdyno ir graikiniai riešutai, pistacijos, menkè, karpis, silkè, lašiša, skumbrè, tunas, kardžuvè, soja, galvijų mėsa, salieras.

Laikantis griežtos hipoalerginès dietos, 1 metų ir 1 mènesio pacientui išsivystė mitybinè - geležies stokos (feritino kiekis kraujyje buvo $3 \mathrm{mcg} / \mathrm{l}$; norma - 25-380 mcg/l) ir vitamino B12 stokos (vit. B12 kiekis kraujyje buvo 45,3 pmol/l; norma - 162-683 pmol/1) anemija: Hb 87 g/l, Ht 27,4\%, MCV 66,8 fl, MCH 21,2 pg. Skirtas gydymas geležies bei vitamino B12 preparatais. Geležies preparatus pacientas toleravo, tačiau, pradejjus vartoti vit. B12 preparatą, $\mathrm{AD}$ bèrimas labai paūmejjo, todèl gydymas juo nutrauktas.

2 mènesius neskyrus pakaitinès imunoterapijos norma-

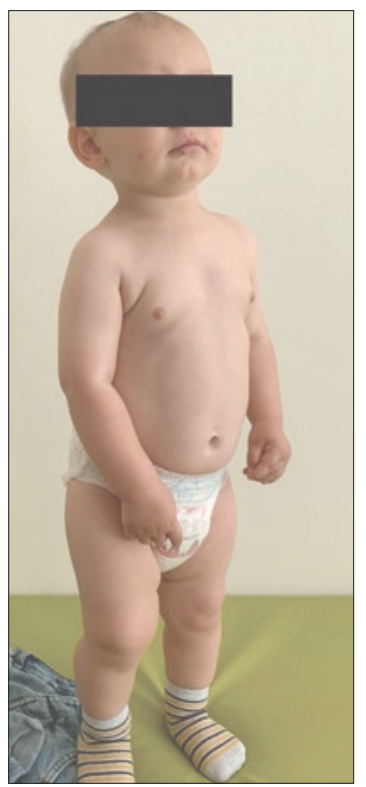

5 pav. Gydymo metu pagerejusi odos būklè liuoju žmogaus imunoglobulinu, nustatyta neigiama IgG kiekio kraujyje dinamika (1 m. amž. $3,4 \mathrm{~g} / 1,1 \mathrm{~m}$. 1 mèn. amž. $-2,0$ $\mathrm{g} / \mathrm{l}$; amžiaus norma 3-10 g/l). Pakartojus imunologinị ištyrimą (imunogramą; imunoglobulinų, IgG poklasių ir anti-HBs kieki kraujyje; monocitų ir granuliocitų fagocitozès aktyvumo nustatymą) ir, stebint mažèjantị IgG kiekị vyresniam negu vieneriu metu pacientui, esant normaliems T ir B limfocitų kiekiams, nesant antikūnų prieš hepatito $B$ paviršini antigeną, diagnozuotas iprastas kintamasis imunodeficitas, nuspręsta tęsti pakaitinę terapiją poodiniu žmogaus normaliuoju imunoglobulinu - Gammanorm. Paciento mama stacionare apmokyta leisti poodinị imunoglobuliną, jis pacientui leidžiamas nuo 1 metų 1 mènesio amžiaus kas 7-10 dienų. Šalutinių reakcijų nestebèta, IgG kiekis svyruoja tarp 8,2-8,4 g/l (amžiaus norma 3,5-10 g/l).

Taikant pakaitinę terapiją normaliuoju žmogaus imunoglobulinu, tęsiant gydymą AD simptomų kontrolei skirtais medikamentais bei toliau laikantis hipoalerginès dietos, paskiausio vizito pas vaikų alergologą metu (tuo metu pacientui buvo $1 \mathrm{~m}$. 10 mèn.) stebèta žymiai pagerèjusi odos būklè - odoje matomi tik pavieniai berimai skruostų, dešiniojo riešo srityse, ženkliai sumažèjęs difuzinis odos sausumas bei lichenifikacija. SCORAD indeksas -35 balai (5 pav.).

\section{Diskusija}

AD yra lètinè, banguojančios eigos odos liga, neretai sukelianti labai stiprų odos niežejjimą ir vientisumo pažeidimą. Veikiant alergenams, vyksta ịsijautrinimas - antigeną pateikiančios ląstelès (antro tipo T limfocitai pagalbininkai (Th2)) perduoda alergeną B limfocitams ir šie ima gaminti specifinius IgE. Nustatyta, kad AD vystymosi metu skirtingi B limfocitu poklasiai i specifinius alergenus gali sureaguoti ivvairiai - skiriasi jų aktyvumas bei diferenciacijos laipsnis, nuo kurių priklauso susidarančiu specifinių alergenams $\operatorname{IgE}$ kiekis [5]. Alergenams patekus pakartotinai, šie jungiasi su jiems specifiniais $\operatorname{IgE}$, kurie prisijungia prie $\mathrm{F}_{c} \varepsilon$ receptoriu, esančių ant efektorinių ląstelių (pvz., mastocitų, bazofilų) paviršiaus. Aktyvavus efektorines ląsteles, atpalaiduojami anksčiau susintetinti mediatoriai (daugiausia histaminas) 
ir indukuojama naujų mediatorių sintezè. Kai kurie IgE, reaguodami savais organizmo antigenais, skatina lètinę AD eigą. Šis atopinio dermatito simptomų atsiradimo mechanizmas susijęs su IgE, kai veikiant mediatoriams, AD simptomai (niežulys, perštejjimas ir kt.) atsiranda greitai (per 0,5 - 2 valandas) po kontakto su alergenu $[5,6]$.

Galimas ir kitas AD patogenezinis mechanizmas. Manoma, kad ji lemia sutrikusi pusiausvyra tarp Th1 bei Th2 ląstelių. Veikiant alergenams, ijautrinami T limfocitai. Th2 limfocitai ima gaminti interleukinus (IL) - IL-4 bei IL-13, o Th22 tipo limfocitai - IL-22. Šie citokinai slopina odos vientisumui svarbaus baltymo filagrino gamybą, taip dar labiau pažeisdami alergenų paveiktos odos barjerinę funkciją [7]. Epidermyje aktyvuojami kalcio kanalai, o tai sukelia limfopoetino didelio kiekio išskyrimą. Šis procesas dar labiau aktyvina Th2 bei Th22 limfocitus. Pasigaminę interleukinai aktyvina B limfocitus bei skatina alergenams specifinių IgE gamybą. Pakartotinai patekus alergenui, T limfocitai proliferuoja ir išskiria didelį kiekị uždegimo mediatorių. Šis mechanizmas yra lètesnis, nei sukeliamas IgE. Alergenui veikiant ịsijautrinusị organizmą, AD klinikiniai simptomai pasireiškia per 2-3 paras [5].

Patogenezès mechanizmų supratimas reikalingas parinkti tinkamiausią gydymą: IgE paskatintų reakcijų metu, simptomus sukelia atpalaiduotas histaminas, todèl jų kontrolei pacientui buvo skirti antihistamininiai vaistai, uždegimas slopintas gliukokortikoidais, o citokinų išskyrimas iš limfocitų sumažintas, skiriant vietinius kalcineurino inhibitorius.

Pacientui pasireiškè dauginès alergijos maistui sindromas, kuri sukèlè aukščiau aprašyti mechanizmai, arba jų derinys. Alergijos maistui mechanizmo supratimas yra svarbus klinikinejje praktikoje, kadangi ne IgE sukeltas alergines reakcijas i maistą diagnozuoti bei interpretuoti yra sunkiau. Pagrindinis alergijos maistui gydymo būdas yra eliminacinè dieta, todèl svarbu nustatyti visus maisto alergenus, kurie provokuoja simptomų atsiradimą [4]. Straipsnyje aprašomam pacientui ligos pradžioje atliekant odos dūrio mėginius (ODM) bei specifinių IgE kraujyje tyrimą, nustatytas ịsijautrinimas vos keliems maisto produktams. Kūdikiui augant, tèvai pastebejo vis naujus maisto alergijos simptomus, tokius kaip dilgèlinę, angioedemą, anafilaksines reakcijas, sukeltas maisto produktų, kuriems anksčiau tokie simptomai nepasireiškè, todèl tyrimus maisto alergijai išaiškinti būtina kartoti. Svarbu atlikti ir kartoti ne vien greitojo tipo reakcijas ị maistą parodančius tyrimus (ODM bei specifinius IgE kraujyje), bet ir lètojo tipo reakcijas į maistą padedančius išaiškinti tyrimus - odos lopo mèginius (OLM). Mūsų pacientui pirmaisiais gyvenimo metais bèrimai buvo išplitę visame kūne, todèl OLM su maistu tyrimas buvo atidètas. Vengiant ODM, eliminacinè dieta taikyta eliminuojant specifinių IgE tyrimų pagalba išaiškintus ịsijautrinimą keliančius maisto produktus, bei tuos, nuo kurių, tėvų pastebèjimu, vaiko odos būklè pablogėdavo.

Atopinio dermatito gydymas yra pakopinis ir priklauso nuo AD sunkumo. Pirmasis žingsnis, gydant lengvą, vidutinio sunkumo, ar sunkų AD, yra provokuojančių veiksnų išaiškinimas ir eliminavimas, odos barjerinès funkcijos atkūrimas, vartojant tinkamus emolientus ir tinkamai prižiūrint odą (palaikant odos rūgštingumą, vartojant mažo $\mathrm{pH}$ prausiklius) [8]. Nepavykstant ligos kontroliuoti vien provokuojančiu veiksnių eliminavimu ir tinkama odos priežiūra, nepriklausomai nuo AD sunkumo, simptomų kontrolei rekomenduojama vartoti antihistamininius vaistus, slopinančius niežulį. Siekiant slopinti AD uždegiminị komponentą, dažnai skiriami vietiniai gliukokortikosteroidai (GKS). Priklausomai nuo ligos paūmejjimo sunkumo ir bèrimo lokalizacijos, skiriami silpnai veikiantys, vidutinio stiprumo arba stipriai (labai stipriai) veikiantys GKS. Kūno vietose, kuriose oda plonesnè (veido, kaklo, pažastų, kūno raukšlių), vartojami silpnai veikiantys vietiniai GKS, o kur oda stora, tinkamesni stipriau veikiantys vietiniai GKS. Sisteminiai GKS rutiniškai nerekomenduojami net ir sergant sunkiu atopiniu dermatitu. Jie skiriami trumpais 7-10 d. kursais, esant sunkiam $\mathrm{AD}$ paūmejjimui, arba tais atvejais, kai kitos priemonès nebeveiksmingos. Kita gydymo pakopa, ypač kai neveiksmingi vietiniai GKS, yra vietiniai kalcineurino inhibitoriai, slopinantys citokinų išskyrimą iš $\mathrm{T}$ limfocitų. Priešingai nei vietiniai GKS, kalcineurino inhibitoriai nesukelia odos atrofijos. Esant vidutinio sunkumo ir sunkiam AD, galima taikyti drékinančių tvarsčių terapiją (po maudymosi vonioje, oda tepama emolientais bei vietiniais GKS, tuomet dedami emolientais sudrékinti tvarsčiai ir uždengiami sausais drabužiais). Sunkaus AD atvejais paaugliams kartais taikoma fototerapija, o esant neveiksmingiems kitiems gydymo metodams, gydant sunkų AD gali būti skiriami sisteminiai imunosupresantai (azatioprinas, ciklosporinas ir kt.) $[9,10]$. Mūsų aprašytu klinikiniu atveju gydymas GKS (vietiniais ir sisteminiais) pacientui buvo paskirtas kelis kartus, stipriai paūmejjus AD simptomams. Vietiniai GKS buvo naudojami galūnių srityse, o veido sričiai naudotas vietinis kalcineurino inhibitorius - pimekrolimo kremas. Niežuliui paūmejjimų metu kontroliuoti skirti antihistamininiai vaistai.

Hipoalerginé dieta gali būti veiksminga, kontroliuojant atopinio dermatito simptomus. Skiriant hipoalerginę dietą vos 3 savaites, stebimas ženklus SCORAD indekso sumažejjimas, statistiškai reikšmingai sumažèja beveik visi jo komponentai (eritema, edema, šlapiavimas, nukasymas, sausumas, niežèjimas, gerèja miego kokybè), išskyrus lichenifikaciją [11]. Tačiau eliminacinès dietos gali sukelti ne tik baltymų, riebalų, angliavandenių, bet ir mineralų (kalcio, magnio, 
fosforo, geležies), vitaminų (vitamino B12, folinès rūgšties ir kt.) deficitą. Dèl galimos kūdikio mitybos nepakankamumo rizikos, griežta hipoalerginè dieta rekomenduojama tik kaip laikinas sprendimas, kontroliuojant sunkų ar vidutinio sunkumo atopinį dermatitą, arba kaip diagnostikos priemonė nustatyti nepageidaujamas reakcijas keliančius maisto produktus [12]. Nustatyta, jog krūtimi maitinami atopiniu dermatitu sergantys kūdikiai, kurių motinos laikèsi hipoalerginès dietos, gavo mažiau nei 75 proc. visų rekomenduojamų maisto medžiagų, išskyrus baltymus ir A vitaminą. Be to, geležies suvartojimas sieke tik 18,7 proc. rekomenduojamo kiekio, dèl to krūtimi maitinamiems kūdikiams gerokai dažniau pasireiškè geležies stokos anemija, nei maitinamiems mišriai ar mišiniais. Priežastis galèjo būti krūtimi maitinamų atopiniu dermatitu sergančių kūdikių motinų pastangos išvengti galimų alergenų, ribojant savo mitybą. Negaudamos pakankamai maistinių medžiagų, nepakankamą jų kiekị išskyrè su pienu [13]. Ištyrus 50 vaikų, sergančių atopiniu dermatitu, 31 (62 proc.) nustatytas folio rūgšties trūkumas ir 21 (42 proc.) - geležies stoka [14]. Šių medžiagų stoka organizme lemia mitybinių anemijų, t. y. geležies stokos, vitamino B12 ir folio rūgšties stokos išsivystymą. Mūsų nagrinèjimu atveju, dèl griežtos hipoalerginès dietos, kurios laikèsi natūraliai maitinanti kūdikị mama, taip pat išsivystė mitybinè (geležies ir vitamino B12 stokos) anemija. Šie rezultatai parodo, kad sunkesnemis atopinio dermatito formomis sergantys pacientai turi didesnę mitybinès anemijos riziką dèl maisto ribojimo, siekiant išvengti ligos paūmejimų.

Mūsų nagrinèjamu atveju pacientui nustatytas pirminis imunodeficitas, kuriam būdingas sumažejęs imunoglobulino $\mathrm{G}$ ir jo poklasių kiekis kraujyje. Nustačius hipoglobulinemiją, pacientus svarbu ištirti dèl atopinių būklių, nes jų dažnis gali būti didesnis, nei bendroje populiacijoje [15]. Ištyrus 160 vaikų, sergančių atopiniu dermatitu ir juos palyginus su 95 sveikų vaikų kontroline grupe, nustatyta, jog AD sergančių vaiku grupeje hipoglobulinemija, dažniausiai sukelta IgG trūkumo, buvo dažnesnè, nei sveikujų grupejje. Statistiškai reikšmingo ryšio tarp hipogamaglobulinemijos ir AD sunkumo nenustatyta [16]. Taikant pakaitinę terapiją žmogaus normaliuoju imunoglobulinu, beveik visiems pacientams, sergantiems sunkiu, atspariu kitam gydymui AD, buvo stebimas klinikinis pagerējimas [17]. Atidžiai gydant ir kruopščiai stebint IgG kiekio pokyčius kraujyje, odos simptomai regresuoja ir serumo IgG koncentracija dažniausiai normalizuojasi iki 2 metų amžiaus [18]. Nagrinejjamuoju atveju, toliau stebint IgG kiekio pokyčius, eliminavus AD paūmèjimus provokuojančius veiksnius, intensyviai drėkinant ir prižiūrint odą, jei reikès, skiriant medikamentinį AD gydymą, pacientui sunkaus AD simptomai ir hipogamaglobulinemija turetų išnykti sulaukus 2 metų ar vèliau.
Sergančiujų AD pažeidžiama normali odos mikroflora - sumažejja mikroorganizmų įvairovè. Kartu sumažejja ir bakterijų, kurios gamina S. aureus inhibitorius, todèl labai dažnai sergančiujų AD odą kolonizuoja S. aureus. Sergančiujų AD odos vientisumas paūmèjimo metu būna pažeistas, todèl dideja pavojingų antrinių infekcijų rizika. Neseniai imta svarstyti apie specifinių imunoglobulinų prieš citokinus bei citokinų receptorius terapijos naudą, siekiant pašalinti S. aureus nuo paciento odos [19]. Nagrinejjamuoju atveju pacientui buvo kilusi antrinè odos infekcija, ị erozijas patekus odą kolonizavusiam $S$. aureus, todèl skirtas sisteminis antibakterinis gydymas. Paciento odos kolonizacijos $S$. aureus kontrolei taikoma pakaitinè imunoterapija normaliuoju žmogaus imunoglobulinu.

\section{Išvados}

1. Atopinis dermatitas gali pasireikšti kaip sunki, negalią sukelianti liga.

2. Atopinị dermatitą gali sukelti tiek su IgE susijusios, tiek nesusijusios ir mišrios imuninès reakcijos.

3. Nuo IgE sukèlusio mechanizmo priklauso diagnostinių tyrimų pasirinkimas bei simptomų kontrolei naudojamų vaistų paskyrimas.

4. Mūsų nagrinètas atvejis parodè, jog esant sunkiai AD formai su dauginès alergijos maistui sindromu ir pirminiu imunodeficitu, liga gali būti kontroliuojama ir gyvenimo kokybe žymiai pagerinama, paskyrus tinkamą kompleksinị gydymą.

\section{Literatūra}

1. Strathie Page S, Weston S, Loh R. Atopic dermatitis in children. Aust Fam Physician 2016;45(5):293-6.

2. Huang E, Ong PY. Severe atopic dermatitis in children. Curr Allergy Asthma Rep 2018;18(6):35,018-0788-4.

https://doi.org/10.1007/s11882-018-0788-4

3. Greenhawt $M$. The role of food allergy in atopic dermatitis. Allergy Asthma Proc 2010;31(5):392-7.

https://doi.org/10.2500/aap.2010.31.3393

4. Cartledge N, Chan S. Atopic dermatitis and food allergy: a paediatric approach. Curr Pediatr Rev 2018;14(3):171-9.

https://doi.org/10.2174/1573396314666180613083616

5. Furue M, Chiba T, Tsuji G, Ulzii D, Kido-Nakahara M, Nakahara $\mathrm{T}$, et al. Atopic dermatitis: immune deviation, barrier dysfunction, $\operatorname{IgE}$ autoreactivity and new therapies. Allergol Int 2017;66(3):398-403.

https://doi.org/10.1016/j.alit.2016.12.002

6. Anvari S, Miller J, Yeh CY, Davis CM. IgE-mediated food allergy. Clin Rev Allergy Immunol 2019;57(2):244-260.

https://doi.org/10.1007/s12016-018-8710-3

7. Munera-Campos M, Carrascosa JM. Innovation in atopic der- 
matitis: from pathogenesis to treatment. Actas Dermosifiliogr 2020;111(3):205-221.

https://doi.org/10.1016/j.adengl.2020.03.001

8. Silverberg NB. Atopic dermatitis prevention and treatment. Cutis 2017;100(3):173;177;192. https://doi.org/10.1016/S0733-8635(17)30058-X

9. Lyons JJ, Milner JD, Stone KD. Atopic dermatitis in children: clinical features, pathophysiology, and treatment. Immunol Allergy Clin North Am 2015;35(1):161-183. https://doi.org/10.1016/j.iac.2014.09.008

10. Lewis-Jones S, Mugglestone MA, Guideline Development Group. Management of atopic eczema in children aged up to 12 years: summary of NICE guidance. BMJ 2007;335(7632):12631264. https://doi.org/10.1136/bmj.39405.503773.AD

11. Celakovska J, Bukac J. Hypoallergenic diet can influence the severity of atopic dermatitis. Indian Journal of Dermatology 2013;58(3):239. https://doi.org/10.4103/0019-5154.110839

12. Celakovská J, Ettlerová K, Ettler K, Bukac J, Belobrádek M. The Effect of hypoallergenic diagnostic diet in adolescents and adult patients suffering from atopic dermatitis. Indian Journal of Dermatology 2012;57(6):428.

https://doi.org/10.4103/0019-5154.103065

13. Han Y, Lee Y, Park H, Park S, Song K. Nutrient intakes of infants with atopic dermatitis and relationship with feeding type. Nutrition Research and Practice 2015;9(1):57.

https://doi.org/10.4162/nrp.2015.9.1.57

14. Cui H, Ahn I, Byun Y, Yang Y, Kim J, Chung B, et al. Dietary pattern and nutrient intake of Korean children with atopic dermatitis. Annals of Dermatology 2014;26(5):570.

https://doi.org/10.5021/ad.2014.26.5.570

15. Dadkhah M, Aghamohammadi A, Movahedi M, Gharagozlou M. Atopic manifestations: dermatitis, allergic rhinitis and asthma in patients with hypogammaglobulinemia. Iranian Journal of Pediatrics 2015;25(5). https://doi.org/10.5812/ijp.2786

16. Celiksoy MH, Topal E, Sancak R, Catal F, Sogut A. Relationship between hypogammaglobulinemia and severity of atopic dermatitis. Ann Allergy Asthma Immunol 2014;113(4):467-9. https://doi.org/10.1016/j.anai.2014.06.025
17. Breslin M, Lin J, Roberts R, Lim K, Stiehm E. Transient hypogammaglobulinemia and severe atopic dermatitis: Open-label treatment with immunoglobulin in a case series. Allergy \& Rhinology 2016;7(2):69-73.

https://doi.org/10.2500/ar.2016.7.0164

18. Wang AS, Liang MG, Schneider LC. Severe atopic dermatitis and transient hypogammaglobulinemia in children. Pediatr Dermatol 2012;29(1):73-8. https://doi.org/10.1111/j.1525-1470.2011.01477.x

19. Geoghegan JA, Irvine AD, Foster TJ. Staphylococcus aureus and atopic dermatitis: a complex and evolving relationship. Trends Microbiol 2018;26(6):484-97.

https://doi.org/10.1016/j.tim.2017.11.008

\section{A CASE REPORT OF SEVERE DIFFUSE ATOPIC DERMATITIS WITH MULTIPLE FOOD ALLERGY SYNDROME AND PRIMARY IMMUNODEFICIENCY}

E. Bučionytė, A. Čibirkaitė, V. Bubnaitienė

Keywords: atopic dermatitis (AD), multiple food allergy syndrome, primary immunodeficiency, children.

Summary

Atopic dermatitis (AD) is a chronic, undulating skin disease that causes severe itching of the skin and violations of its integrity. As many as $20 \%$ of infants and children under the age of 2 are exposed to AD and about a third of these children have AD symptoms associated with food allergy. It is important to remember that $\mathrm{AD}$ sometimes occurs with primary immunodeficiency, and the skin of children with AD is often colonized by Staphylococcus aureus ( $S$. aureus). AD can present as a severe, disabling disease. It can be caused by IgE-related or unrelated and mixed immune reactions. The choice of diagnostic tests and the prescription of symptom control medications are dependent on the mechanism of IgE induction. In severe form of $\mathrm{AD}$ with multiple food allergy syndrome and primary immunodeficiency, the disease can be controlled and quality of life significantly improved by prescribing appropriate combination therapy. This article presents a severe case of atopic dermatitis, which has occurred in combination with multiple food allergy syndrome and primary immunodeficiency.

Correspondence to: evelina.bucionyte@stud.lsmu.lt

Gauta 2020-12-15 